\author{
Luljeta Plakolli-Kasumi, LL.M. ${ }^{1}$ \\ University of Pristina "Hasan Prishtina", Law Faculty, Kosovo
}

\title{
SOME PRELIMINARY FINDINGS REGARDING THE KOSOVO LEGISLATION IN THE FIELD OF CONSUMER PROTECTION WITH SPECIAL EMPHASIS IN ARBITRATION CLAUSES IN CONSUMER CONTRACTS
}

UDK: $366.5(497.115)$

DOI: 10.31141/zrpfs.2020.57.137.875

Izvorni znanstveni rad

Primljeno: 10. 11. 2019.

\begin{abstract}
Although the Kosovo Law on Consumer Protection has been harmonized with the EU Directive on Unfair Contract Terms, several inconsistencies are still prevalent in other pieces of legislation, which in turn diminish the effective protection of consumers in line with the aim of the said Directive. The present paper aims at introducing some preliminary findings of the author's doctoral thesis which can serve as a basis for further improvement of the existing legislation in the field of consumer protection. Full harmonization of the consumer protection legislation with the Unfair Terms Directive entails not only the verbatim transposition of the said Directive into one piece of legislation but an alignment of the entire legislative framework to this end, as well as the development of the court practice in line with the CJEU case-law.
\end{abstract}

Key words: arbitration, consumer, consumer protection, standard form contracts, unfair terms

\section{INTRODUCTION}

Consumer protection is guaranteed by the Constitution of the Republic of Kosovo $^{2}$, and is governed by more than 30 laws and bylaws. ${ }^{3}$ First law governing consumer protection was promulgated under the UNMIK administration ${ }^{4}$, which aimed at determining, regulating and protecting fundamental consumer rights during the purchase of goods and services in a free market economy. ${ }^{5}$ The law was nonetheless vague both in terms of its content and scope, failed to meet the demands of that time, and it was not aligned with the EU acquis. The law remained into force until 2012 when it was repealed by Law 04/L-121 on Consumer Protection.

Luljeta Plakolli-Kasumi, LL.M., e-mail: luljeta.plakolli@gmail.com

2 Official Gazette of the Republic of Kosovo, Constitution of the Republic of Kosovo (2008), Article 119 , par. 7

10)

3 Government of the Republic of Kosovo, 'Consumer Protection Program (2016-2020)' 2005 (page

4 UNMIK, Law 2004/17 on Consumer Protection as amended and supplemented)

5 Article 1 of the Law 2004/17 on Consumer Protection 
The new law attempted to fill in the gaps of the repealed law. On 27 October 2015, the Republic of Kosovo and the European Union signed the Stabilisation and Association Agreement (SAA), which was approved by the Kosovo Government on 30 October 2015 through the decision no. 01/55 on approval of the draft Law on Ratification of the Stabilisation and Association Agreement between the European Union and the European Atomic Energy Community, of the one part, and Kosovo, of the other part. ${ }^{6}$ According to the Kosovo Constitution, the SAA was ratified by the Kosovo Assembly on 2 November 2015 with the adoption of the Law on Ratification of the Stabilisation and Association Agreement. ${ }^{7}$

In the light of the SAA, Kosovo undertook an obligation to approximate its legislation with the EU acquis. Article 81 of the SAA provides, inter alia, the obligation for Kosovo to cooperate with the EU in approximating its legislation in the field of consumer protection and ensuring effective legal protection for consumers. In this regard, the Council Directive 93/13/EEC of 5 April 1995 on Unfair Contract Terms in Consumer Contracts (hereinafter referred to as 'Unfair Terms Directive'), represents an EU mechanism in the field of consumer protection with which Kosovo legislation must be fully aligned. Consequently, in 2018 the Kosovo Assembly adopted the new Law on Consumer Protection. ${ }^{8}$

Although the Law on Consumer Protection has been harmonized with the EU acquis, several other pieces of legislation in Kosovo contain provisions which contradict this law, thus giving rise to different interpretations to the detriment of consumers. The present paper focuses on arbitration clauses contained in consumer contracts and aims at putting forward some practical implications which may derive from the abovementioned discrepancies. The analysis in this paper is limited to the Law on Arbitration, as well as the Regulation of the Central Bank of Kosovo for Procedures of the Arbitral Tribunal. A more detailed analysis is therefore needed to determine the number of other laws that need to be further aligned with the Law on Consumer Protection for an optimum harmonization with the EU acquis in this field. These two pieces of legislation, which are at the focus of the paper, are especially important since if not aligned with the Law on Consumer Protection can mislead courts in interpreting the validity of arbitration clauses contained in consumer contracts, and thus pose serious repercussions for consumers.

6 Government of the Republic of Kosovo, Decision No. 01/55 of 30.10.2015

Kosovo Assembly, Law No.05/L-069 on Ratification of the Stabilisation and Association Agreement between the European Union and the European Atomic Energy Community, of the one part, and Kosovo, of the other part.

8 Kosovo Assembly, Law No. 06/034 on Consumer Protection, promulgated in the Official Gazette of the Republic of Kosovo on 14 June 2018 


\section{HARMONIZATION OF THE KOSOVO LEGISLATION WITH THE EC DIRECTIVE ON UNFAIR TERMS IN CONSUMER CONTRACTS}

Chapter IX of the Law on Consumer Protection contains provisions on unfair contract terms in consumer contracts and has made a verbatim transposition of the general criteria contained in Article 3(1)24 as well as the additional criteria contained in the Annex of the Unfair Terms Directive, which provides for the indicative list of unfair contract terms. Namely, Article 71 of the Law on Consumer Protection provides that 'a contractual term which has not been individually negotiated shall be considered as unfair if contrary to the requirements of good faith creates a significant imbalance in the rights and obligations of the contractual parties, to the detriment of the consumer'. Further Article 72 of the Law contains the list of unfair contract terms and in par.1.17 it provides that any clause that excludes or deprives the consumer to undertake legal actions or to exercise any other legal remedy, especially by asking the consumer to refer disputes exclusively to arbitration not covered by legal provisions is considered an unfair contract term.

The Unfair Terms Directive applies to all consumer contracts, including insurance contracts. ${ }^{9}$ Only contracts relating to employment, contracts relating to succession rights, contracts under family law, and contracts relating to the incorporation and organization of companies or partnership agreements are excluded from the Directive.$^{10}$ Chapter IX of the Law on Consumer Protection is in full compliance with the Unfair Terms Directive and it applies to all consumer contracts except those which are excluded from the scope of the Unfair Terms Directive. The Law has been also harmonized with the Consumer Rights Directive ${ }^{11}$, and Chapter VII of the Law provides that provisions related to the distance contracts and contracts concluded outside of business premises, do not apply to several contracts, including financial contracts, in line with the Consumer Rights Directive.

Despite this sufficient transposition of the Unfair Terms Directive in the Law on Consumer Protection, the Law on Arbitration contains provisions that create ambiguities concerning whether and when an arbitration clause is deemed as an unfair contract term in consumer contracts. Further, the Regulation on Arbitration Procedures enacted by the Central Bank of Kosovo in 2017, which aims at setting forth procedures for the functioning of arbitration tribunals for insurance companies, insurance holders, and third parties, deviates even more from the aim of the Law on Consumer Protection and adds to this misperception. Although both the Law on Arbitration and the CBK Regulation have been enacted before the entrance

9 Merryl Dean, 'Legislation: Unfair Contract Terms: The European Approach” [Vol. 56, 1993], The Modern Law Review Limited, page 581

10 Council Directive 93/13/EEC of 5 April 1993 on Unfair Terms in Consumer Contracts (Recitals)

11 Directive 2011/83/EU of the European Parliament and of the Council of 25 October 2011 on consumer rights, amending Council Directive 93/13/EEC and Directive 1999/44/EC of the European Parliament and of the Council and repealing Council Directive 85/577/EEC and Directive 97/7/EC of the European Parliament and of the Council, OJ L034/64, 22.11.2011 
into force of the Law on Consumer Protection, no actions undertaken so far by the legislator and the regulator to amend these pieces of legislation confine full harmonization of the Kosovo legislation with the EU acquis in the field of consumer protection as required by the SAA.

\subsection{Law on Arbitration vs Law on Consumer Protection}

The Kosovo Law on Arbitration was enacted in $2008^{12}$ as lex specialis thus repealing provisions of the Law on Contested Procedure ${ }^{13}$ pertaining to arbitration proceedings. The Law on Arbitration provides for the rules that apply to arbitration agreements and arbitration proceedings, as well as provisions on the recognition and enforcement of arbitral awards. The Law on Arbitration is based on the UNCITRAL Model Law (2006 version). Article 2 of the Law on Arbitration defines the 'arbitration agreement' as an agreement reached between two or more persons to refer one or all legal disputes which arose or may arise between them to arbitration. The 'consumer' is defined as any natural person who concludes a contract for purposes which are outside his trade, business or profession. ${ }^{14}$ While the Law on Arbitration is suitable for B2B disputes, its provisions are not suitable for B2C disputes. When analyzed in the light of the consumer protection law, several criticisms must be put forward in relation to the Law on Arbitration.

The first problem relates to Article 6 par.3 of the Law on Arbitration according to which, if a consumer is a party to an arbitration agreement, it is deemed to have been concluded only if the parties have personally signed the document containing the arbitration clause. This requirement of the law is deemed to have been satisfied if it can be substituted with an electronic signature under the applicable legislation on e-signatures.$^{15}$ From the wording of this provision, it is implied that any standard form contract containing an arbitration clause, which has been personally signed by both parties will result in a valid arbitration agreement. This is contrary to the purpose of the Unfair Terms Directive and the Law on Consumer Protection. In some jurisdictions, such as Germany ${ }^{16}$ and Luxembourg ${ }^{17}$, an arbitration agreement when the consumer is a party shall be considered to be valid, only if such an agreement is signed as a separated document from the main contract, by thus demonstrating

12 Official Gazette of the Republic of Kosovo 37/2008, Law No.02/L-75 on Arbitration

13 Official Gazette of the Republic of Kosovo 38/2008, Law No.03/L-006 on Contested Procedure (as amended and supplemented in 2012)

14 Supra note 11, Article 2

15 Ibidem, Article 6, par.3

16 See Germany: Code of Civil Procedure of 5 December 2005 [Federal Official Gazette page 3202; 2006 I page 431; 2007 I page 1781], last amended by Article 1 of the Act dated 10 October 2013 (Federal Law Gazette I page 3786), <(https://www.gesetze-im-internet.de/englisch_zpo/englisch_zpo. html> accessed 11 December 2019; see also Germany: Arbitration Act of $1998<$ https://sccinstitute.com/ media/29988/german-arbitration-act.pdf> accessed 11 December 2019

17 Luxembourg: Civil Code of 1803, 1135-1 < http://legilux.public.lu/eli/etat/leg/code/civil/ 20190428> accessed 11 December 2019 
the will of the consumer to refer the dispute to arbitration. ${ }^{18}$ The aim here is to separate the consent for the main contract from the consent to refer the dispute to arbitration, by ensuring that consumers are not forced to waive their right to refer their disputes to the court (Croatia, Czech Republic, Germany, Poland, and Romania). ${ }^{19}$ A peculiar thing about these systems is that a standard form contract concluded between the business and a consumer containing an arbitration clause will not perform the function of an arbitration agreement, even if it is personally signed by the consumer. Hence, Article 6, par.3 of the Law on Arbitration shall be amended to reflect this aim.

The second problem derives from paragraph 4 of Article 6 of the Law on Arbitration. According to Prof. Morina, when the party to the arbitration agreement is a consumer, Article 6 par. 4 of the Law on Arbitration applies, and according to this provision, any non-compliance with the form requirement specified in paragraph 3 shall not be considered by an arbitration tribunal if the parties initiate arbitration proceedings..$^{20}$ This is a matter of opinion with which the author of the present paper disagrees since the review of the literature as well as the analysis of the case-law of CJEU undertaken confirms that while this may stand as true from the perspective of the arbitration law, the situation changes when analyzed from the perspective of the consumer protection law. As currently provided by the Law on Arbitration, this provision can have severe consequences on consumers, who in the total lack of knowledge and awareness about the content of the standard form contract, even without personally signing the contract containing the arbitration clause, will be bound by the arbitration clause just because they did not object the commencement of the arbitration proceedings. This is also not consistent with the requirements of the Unfair Terms Directive which requires EU member states to foresee into their national legislations that consumers shall not be bound by unfair contract terms. Consequently, the Law on Consumer Protection also provides that unfair terms used in a contract concluded with a consumer by a seller or supplier shall be null and that the contract shall continue to legally bind the parties if it is capable of continuing in existence without the unfair terms. ${ }^{21}$

The Unfair Term Directive requires from EU member states to foresee onto their national legislations that unfair terms shall not be mandatory for the parties, but it does not give any indication whether every arbitration clause is unfair. Therefore, the validity of the arbitration clause shall be analyzed on a case by case basis.

18 Cole et al, 'Legal Instruments and Practice of Arbitration in the EU' in Study of the DirectorateGeneral for Internal Policies, Legal Affairs, Policy Department C: Citizens' Rights and Constitutional Affairs', European Parliament, (2014), 55 < http://www.europarl.europa.eu/RegData/etudes/STUD/2015/ 509988/IPOL_STU(2015)509988_EN.pdf> accessed 11 December 2019

19 Ibidem

20 Iset Morina, 'Arbitrazhi dhe Procedura e Arbitrazhit', (2015), Kosovo Permanent Tribunal of Arbitration, pp. 145-146

21 Supra note 7, Article 75, par.1 (Straetmans, 2017) (Piers, 2013) (Oceano Grupo Editorial SA v Rocio Murciano Quintero and Emilio Vinas Feliu) (Regulation on Procedures of the Arbitration Tribunal, 2017) (Katalin Sebestyen v Zsolt Csaba Kovari OTP Bank, OTP Faktoring Koveteleskezelo Zrt, Raiffeisen Bank Zrt) 
The Kosovo Law on Consumer Protection provides the same, and the arbitration clause contained in consumer contracts must be assessed by the courts in light of the criteria provided by the Unfair Terms Directive.

The significant imbalance, good faith, and transparency are three criteria foreseen by the Unfair Terms Directive and as interpreted by the CJEU, and which shall be cumulatively taken into account during the assessment of an unfair contract term, and these criteria may be taken into account when assessing the unfairness of the term from the substantive as well as procedural aspect. ${ }^{22}$

Therefore, for an arbitration agreement to be able to pass the 'fairness' test in the light of the Law on Consumer Protection, the Arbitration Law shall be amended to either provide that an arbitration agreement involving a consumer shall be deemed valid if concluded only after the dispute has arisen ${ }^{23}$; or is signed in a document which is separate from the main contract ${ }^{24}$, so that the consumer is aware of its existence and can make a better-informed decision when agreeing to arbitration; or if the arbitration clause is not exclusive and leaves as an open option for parties to opt to court as well for dispute resolution

In view of the above, the Kosovo Law on Arbitration must be amended to determine specific formal requirements for consumers, in line with the Law on Consumer Protection as well as the purpose of the Unfair Terms Directive, otherwise, it will be very difficult for courts to balance the application of principles contained in the arbitration law with those contained in the consumer protection legislation. There are a number of scholarly debates on the modalities according to which consumer arbitration would be possible without conflicting with the Unfair Terms Directive. One of them is Maud Piers, who suggests that the essence of the problem related to consumer arbitration in Europe is that the existing arbitration laws contain provisions, which are suitable only for business disputes, and national legislation of EU member states have the tendency to not take into account characteristics or special rules of consumer arbitration. ${ }^{25}$ In other words, according to Piers, an arbitration law cannot be applied to two different procedures because arbitration rules that have been developed with business disputes in mind cannot produce required results in consumer disputes. ${ }^{26}$

22 Geraint Howells and Gert Straetmans, 'The Interpretive Function of the CJEU and the Interrelationship of EU and National Levels of Consumer Protection', [Vol.9, Issue 2, 2017] Perspectives of Federalism, page 188

23 Supra note 17, Cole et al, page 55; in jurisdictions such as Austria, Denmark, Finland, Ireland, Lithuania, Slovenia and Sweden, the consumer may not agree to arbitration before any dispute has arisen, and consequently, such arbitration clauses in consumer contracts shall be deemed invalid.

24 Ibidem

25 Maud Piers, 'Consumer Arbitration and European Private Law: A Seminal Consumer Arbitration Model Law for Europe' (2013) 21 European Review of Private Law, Issue 1, pp. 247-288

26 Ibidem 


\subsection{CBK Regulation vs. Law on Consumer Protection}

It is a well-established practice of insurance companies to use standard form contracts with consumers. Under the Law on Consumer Protection, if these standard form contracts contain an arbitration clause, such a clause is considered to be an unfair term, and the consumer can request the court to declare such a term invalid due to its unfair character. Furthermore, according to the case-law established by the CJEU, the court can also decide on its own motion on the validity of such a contractual term. ${ }^{27}$ Notwithstanding this fact, in 2017 the Central Bank of Kosovo (hereinafter referred to as 'CBK'), enacted the Regulation on Procedures of the Arbitration Tribunal ${ }^{28}$, which contains procedural provisions for arbitration tribunal when deciding on disputes arising from contracts concluded between consumers and insurance policies. Article 3 of this Regulation seems to disregard the fact that the contracts concluded between insurance companies and consumers fall within the scope of the Law on Consumer Protection and therefore its provisions contradict the law.

As explained above, according to Article 6 par. 3 of the Law on Arbitration, if the consumer is a party to an arbitration agreement, such an agreement shall be considered to have been concluded in writing only if all the parties to the arbitration agreement have personally signed the document containing the arbitration clause. Contrary to this, the said Regulation contains a provision that can be significantly harmful to the consumer since it provides that the requirement of an agreement 'in writing' is satisfied if it has been concluded through the exchange of letters, telegrams or other means which provide written evidence of the agreement. ${ }^{29}$ The CBK Regulation has taken this provision verbatim from the Law on Arbitration, which does not apply to cases when the consumer is a party to the arbitration agreement. Instead of this, Article 6 par. 3 of the Arbitration Law provides for more stringent provision (although not ideal in the light of the Consumer Protection Law as elaborated above), requiring the personal signature of the consumer in the document containing the arbitration clause. When the consumer is a party to the arbitration agreement, the exchange of letters and other means of communication are not sufficient to determine the will of the consumer to enter into an arbitration agreement, but instead, both parties must personally sign the document containing the arbitration clause ${ }^{30}$, although this is also disputable in light of the analysis above in this paper. This can have serious ramifications for consumers who may unknowingly give the consent to refer any dispute arising out or in connection with the insurance contract through means of exchange of letter, or emails thus depriving them of exercising their right to undertake legal actions in the court of law or to exercise any other legal remedy. The Regulation contradicts both the Law

27 Joined Case C-240/98 Océano Grupo Editorial SA v Roció Murciano Quintero, to Case C-244/98 Emilio Vinas Feliu, I:4963

28 Central Bank of Kosovo, Regulation on Procedures of the Arbitration Tribunal of 13 March 2017

29 CBK Regulation, Article 3 par. 2

30. Supra note 19, Morina page 144 
on Arbitration as well as the Law on Consumer Protection and should be therefore amended in the light of recent legislative changes.

Competencies of the CBK for the promulgation of this Regulation derive from the Law on Insurance, namely articles 4 and 55 of the Law. Article 55 of the Law on Insurance contains provisions that govern disputes, and paragraph 4 of the same article provides that the CBK may establish an arbitration forum for the resolution of disputes between parties to an insurance contract and can further provide for procedural rules through regulation. Paragraph 1 of Article 55 provides that the insurance company, which is a legal entity, drafts and adopts internal procedures that will apply when parties agree to refer their disputes to arbitration. The Law on Insurance also provides that the insurance company shall publish the pre-contractual information on out of court dispute settlement procedures as part of the insurance contract terms. In case of any dispute deriving from the ambiguous language used in the insurance contract, the contra preferentem rule shall apply, meaning that terms of such a contract shall be interpreted in the favor of the consumer. This is an attempt of the legislator to give to arbitration clauses contained in insurance contracts a 'fair' character but to no avail, because as it can be observed from the case-law of the CJEU, the mere publication of the information on out-of-court settlement of disputes as part of the contract is not in itself sufficient to ensure the fairness of a contract term in consumer contract. ${ }^{31}$

For insurance companies, it will not suffice to only foresee in their internal procedures that such pre-contractual information on the possibility of referring the dispute to arbitration is given to the consumer. In light of the criteria set out under the Unfair Terms Directive, and under the consumer protection law, the court shall always declare an arbitration clause contained in an insurance contract invalid, and shall not enforce an arbitral award because such term creates in lack of good faith, a significant imbalance in the rights and obligations of contractual parties, to the detriment of the consumer. For an arbitration clause in the insurance contract to be valid and pass the 'fairness' test, it must also be provided in a document that is separated from the main contract and must be drafted in clear and plain language, understandable to the consumer.

\section{CONCLUSIONS}

The preliminary findings in this paper are expected to lead to a better understanding of Kosovo policymakers, regulators, law practitioners as well as academia of the overall aim of the Unfair Terms Directive and implications deriving from harmonization of the Law on Consumer Protection with the said Directive. Insights into the existing discrepancies between the Law on Consumer Protection in one hand, and the Law on Arbitration as well as the CBK Regulation on the

31 Case C-342/13 Katalin Sebestyén v Zsolt Csaba Kővári, OTP Bank, OTP Faktoring Követeléskezelő Zrt, Raiffeisen Bank Zrt, OJ: JOC_2014_184_R_001 
other, tend to overcome the potential negative effects that may occur from wrongful application of the provisions contained therein, and which can be burdensome as well as detrimental to the consumers.

The SAA concluded with the EU in its Article 81 provides for an obligation of Kosovo to approximate its legislation on consumer protection to the EU acquis to ensure, inter-alia the harmonization of legislation of consumer protection in Kosovo with that in force in the EU, as well as the effective legal protection for consumers and monitoring of rules by competent authorities and providing access to appropriate legal redress in case of disputes. Full approximation of the consumer protection legislation with the Unfair Terms Directive entails not only the verbatim transposition of the said Directive into one piece of legislation but an alignment of the entire legislative framework to this end, as well as the development of the court practice in line with the CJEU case-law.

\section{List of Abbreviations}

$\begin{array}{ll}\text { B2B } & \text { Business to Business } \\ \text { B2C } & \text { Business to Consumers } \\ \text { CBK } & \text { Central Bank of Kosovo } \\ \text { CJEU } & \text { Court of Justice of the European Union } \\ \text { EC } & \text { European Commission } \\ \text { EU } & \text { European Union } \\ \text { SAA } & \text { Stabilisation and Association Agreement } \\ \text { UNMIK } & \text { United Nations Mission in Kosovo }\end{array}$

\section{REFERENCES}

\section{Authors}

1. Cole et al (2014). Legal Instruments and Practice of Arbitration in the EU. Study of the Directorate-General for Internal Policies, Legal Affairs, Policy Department C: Citizens' Rights and Constitutional Affairs. Retrieved 12 11, 2019, from http://www. europarl.europa.eu/RegData/etudes/STUD/2015/509988/IPOL_STU(2015)509988_ ENG.pdf

2. Dean, M. (1993). Legislation: Unfair Contract Terms: The European Approach

3. Morina, I. (2015). Arbitrazhi dhe Procedura e Arbitrazhit. Pristina: Kosovo Permanent Tribunal of Arbitration.

4. Piers, M. (2013). Consumer Arbitration and European Private Law: A Seminal Consumer Arbitration Model Law for Europe. European Review of Private Law(1)

5. Straetmans, G. H. (2017). The Interpretative Function of the CJEU and the InterRelationship of EU and National Levels of Consumer Protection. Perspectives of Federalism, 9(2) 


\section{EU Legislation}

1. Council Directive 93/13/EEC of 5 April 1993 on Unfair Terms in Consumer Contracts

2. Directive 2011/83/EU of the European Parliament and of the Council of 25 October 2011 on consumer rights, amending Council Directive 93/13/EEC and Directive 1999/44/EC of the European Parliament and of the Council repealing Council Directive 85/577/EEC and Directive 97/7/EC of the European Parliament and of the Council, OJ L034/64

\section{International Legislation}

1. Civil Code. (1803). Luxembourg. Retrieved 12 11, 2019, from http://legilux.public. lu/eli/etat/leg/code/civil/20190428

2. Code of Civil Procedure. (2005, 12 5). Germany: Federal Official Gazette. Retrieved 12 11, 2019, from http://www.gesetze-im-internet.de/englisch_zpo/englisch_zpo. $\mathrm{html}$

\section{Kosovo Legislation}

1. Constitution of the Republic of Kosovo (2008) Official Gazette of the Republic of Kosovo.

2. Law 2004/17 on Consumer Protection. (n.d.). UNMIK.

3. Law No. 02/L-75 on Arbitration (2008) Official Gazette of the Republic of Kosovo

4. Law No. 06/034 on Consumer Protection (2018) Official Gazette of the Republic of Kosovo.

5. Law No.03/L-006 on Contested Procedure (as amended and supplemented in 2012) Official Gazette of the Republic of Kosovo.

6. Law No.05/L-069 on Ratification of the Stabilisation and Association Agreement between the European Union and the European Atomic Energy Community, of the one part, and Kosovo, of the other part, Kosovo Assembly.

7. Regulation on Procedures of the Arbitration Tribunal. (2017, March 13). Central Bank of Kosovo.

\section{Case-Law of the Court of Justice of the European Union}

1. Case C-342/13 Katalin Sebestyen v Zsolt Csaba Kovari OTP Bank, OTP Faktoring Koveteleskezelo Zrt, Raiffeisen Bank Zrt

2. Joined Cases Oceano Grupo Editorial SA v Rocio Murciano Quintero and Emilio Vinas Feliu, C-240/98 to C-244/98

\section{Other documents}

1. Consumer Protection Program (2016-2020). (2005). Government of the Republic of Kosovo. 


\section{NEKI PREDHODNI ZAKLJUČCI U VEZI SA ZAKONODAVSTVOM KOSOVA NA PODRUČJU ZAŠTITE POTROŠAČA S POSEBNIM NAGLASKOM O KLAUZULI O ARBITRAŽI U POTROŠAČKIM UGOVORIMA}

Iako je Kosovski zakon o zaštiti potrošača usklađen s Direktivom EU o nepoštenim uvjetima ugovora, u ostalim su zakonima i dalje prisutne određene nedosljednosti, što zauzvrat umanjuje efikasnu zaštitu potrošača u skladu s ciljem navedene Direktive. Ovaj rad ima za cilj ukazati na neke preliminarne nalaze naše doktorske teze koji mogu poslužiti kao osnova za daljnje poboljšanje postojećeg zakonodavstva u području zaštite potrošača. Potpuno usklađivanje zakonodavstva o zaštiti potrošača s Direktivom o nepoštenim uvjetima podrazumijeva ne samo doslovni prijenos navedene direktive u jedan dio zakona, već usklađivanje cjelokupnog zakonodavnog okvira s tim ciljem, kao i razvoj sudske prakse u skladu s tim sudskom praksom Suda Evropske Unije.

Ključne riječi: arbitraža, potrošač, zaštita potrošača, ugovori standardnog oblika, nepošteni uvjeti 